\title{
User Experience Analysis on Mobile Application Design Using User Experience Questionnaire
}

\author{
I D Sabukunze*1, A Arakaza ${ }^{2}$ \\ ${ }^{1}$ Department of Informatics, Universitas Atma Jaya Yogyakarta, Indonesia \\ ${ }^{2}$ Institut Supérieur de Gestion des Entreprises (ISGE), Kamenge-Bujumbura, Burundi \\ E-mail:205303248@students.uajy.ac.id1, arakaza64@gmail.com2
}

Submitted: 8 July 2021, revised: 23 July 2021, accepted: 26 July 2021

\begin{abstract}
Abstrak. Saat ini, penggunaan konsep interaksi manusia dengan komputer merupakan hal yang sangat penting jika dikaitkan dengan desain aplikasi seluler. Penelitian ini bertujuan untuk menganalisis pengalaman pengguna aplikasi mobile Grab, khususnya pengguna layanan makanan Grab food dengan menggunakan kuesioner pengalaman pengguna. Peneliti melihat beberapa keluhan pengguna Grab food, seperti keluhan terkait lokasi, harga, dan pembayaran. Data tersebut kemudian dianalisis menggunakan Ms Excel. Temuan menunjukkan bahwa dari keenam skala User Experience Questionnaire (UEQ) semuanya baik kecuali skala ketergantungan. Hasil penelitian menunjukkan bahwa nilai variabel attractiveness adalah 1,64, perspicuity 1,69, dependability 1,29, efficiency 1,60, stimulation 1,57, dan kebaruan 1,21. Selain itu, nilai skala ratarata yang dihitung menguntungkan, dan semua nilai lebih signifikan dari 0,8 dibandingkan dengan tolok ukur UEQ. Temuan dapat digunakan untuk peningkatan ketergantungan untuk mengurangi keluhan dari pengguna.
\end{abstract}

Kata kunci: pengalaman pengguna, perancangan, UEQ, usability

Abstract. Nowadays, it is essential to use all concepts of Human-Computer Interaction to understand mobile application design usability. This manuscript aims to analyze a mobile application user experience (Grab online transportation), especially Grab foodservice users, using a user experience questionnaire. We noticed some Grab food users' complaints, such as complaints related to the location, price, and payment. The data was then analyzed using an excel data analysis tool. The findings showed that all six scales of the User Experience Questionnaire (UEQ) were good except the dependability scale. The outcome indicated that the value of attractiveness was 1.64 , perspicuity 1.69 , dependability 1.29 , efficiency 1.60 , stimulation 1.57 , and novelty 1.21 . In addition, the mean scale value computed was favorable, and all values were more significant than 0.8 compared to the UEQ benchmark. The findings can be used for dependability improvement to reduce complaints from users.

Keywords: user experience, design, UEQ, usability 


\section{Introduction}

Recently, there are many areas of research, which can be attributed to the use of mobile application design. A good plan of mobile application facilitates easy interaction and reduces errors to users [1]. Therefore, the usability research of mobile apps design is very prominent and critical in the system development. Mobile app design fluctuates based on different implementation business sectors regarding methods, purposes, and design quality [2]. In improving healthcare provision, mobile applications increase patient security by decreasing medical mistakes [3]. It is necessary to use all the concepts of Human-Computer Interaction to understand mobile app design usability.

The Human-Computer Interaction research topic was once examined the usability, yet has since suited more pleasure in comprehension, planning, and assessing an ample area of user experience details. Technically, understanding the design creates the need for the system to be developed [4]. Interactive methods should be developed based on their usability and user experience purposes [5]. Usability purposes are often associated with detailed usability engineering, such as system design being efficient, effective, and easy to use [6]. User experience is essential for the designer's products to increase customer satisfaction and motivate user interaction. User experience purposes describe the user experience essence, such as interactions more pleasing, delightful, attractive interactions [7].

In Human-computer Interaction (HCI) study sector, the idea of user experience has been noticed as a principal and fascinating research topic. User experience often involves a person's experience when they interact with a product in specific terms. The user experience is centralized to mobile application design [8]. User experience is a kit of technologies to enhance customer satisfaction by boosting usability and interaction between users and computers [9]. Hinderks, et al [10] defined user experience as someone's opinion and feedback derived from the (intended) use of a product, system, or service. Better design of the mobile application makes the user have a good experience while using this system.

Nowadays, mobile phone technology has become an ordinary and necessary tool for modern life. Since the scale of mobile device usage has increased with more than $77.5 \%$ of smartphone users of the globe [11], mobile applications have become popular. Different mobile applications are offered for these mobile devices under additional entertainment, health, lifestyle, and others. A good aspect of mobile application varies notably from one to another based on the way there have been developed [11]. One of the sectors where mobile technology is most used is education because there are used as a platform for teaching and learning [12].

Since the making of the first smartphones, mobile phone usability issues have been relying on the educational communities and software traders manufacturing. It is extensively recognized that usability is an essential sector in software development [11]. Usability testing is applied in such research to evaluate the usability of a mobile application in an activity.

With the inception of the pandemic covid 19, many businesses have gone down, including online transportation business which is not running as well as before [13]. The researchers noticed complaints' users on the Google Play Store. Several users experience identifying problems when interacting with online transportation services because such systems were not designed based on the relevant User Experience Questionnaire. The study conducted by [14] showed that Grab mobile application users met some challenges while using the Grab services, such as complex payment, difficulty in finding addresses, confusion when the user's location does not match the map, and high price [15].

Based on those shortcomings, this study aims to provide an analysis on the user experience of online transportation mobile applications based on the User Experience Questionnaire (UEQ). This manuscript will focus on Grab's online transportation mobile application, 5.158.0 version as a case study, especially Grab food service.

As additional information, Grab mobile application is a popular online transportation in Indonesia since 2012. It is one of the fastest-growing online transportation platforms in Indonesia. People use Grab

Sabukunze, Arakaza (User Experience Analysis on Mobile Application Design Using User Experience Questionnaire) 
to order food, online transportation, and other types of services offered by Grab. In addition, the application accepts different kinds of payment, such as cash after service or e-money (OVO).

\section{Literature study}

\subsection{Usability and Usability testing}

System Usability Scale permits to review of a wide range of products and services, including hardware, software, mobile devices, and websites [16]. It provides a "fast and dirty," reliable tool for measuring usability. Various measures for measuring usability, such as the Computer System Usability Questionnaire [17], evolved for a group of a vast number of ended questionnaires to determine if the structural value found for the PSSUQ in a usability test will remain the study mailed. The SUS has befitted the most popular questionnaire for usability evaluation, usability research, and the survey [17]. Studies have revealed that SUS gives the most reliable validity and sensitivity to an extensive range of independent variables [17].

Usability is the study that links systems and the users [18]. Since most software program design seems to be inadequate to meet customer needs, various research has been directed on the usability, which leads to a better and more relevant understanding measures intended to cover all pertinent scenarios of one foundation or model [19]. Usability testing is a technique to evaluate the usability used to selfevaluate a product by experimenting on user agents in environmental agents [20]. To attain functional application, however, it is necessary to expand the standard of living for explicitly discussing usability issues. Usability testing uses measurable factors, namely efficiency, and effectiveness, to evaluate performers' actions [21].

The International Organization for Standardization (ISO) defines usability as "the expanse to which professionals can use an outcome to achieve specific goals with efficiency, effectiveness, and satisfaction in a particular area of application" [22]. The usability bears all details of usage such as learnability, regular usage, accessibility, and maintainability [23]. Learnability refers to the ability of new users to use the new system efficiently, effectively, and satisfied. Regular usability means that users can reach their objectives with effectiveness, efficiency, and satisfaction. Accessibility indicates that product is accessible and usable for users and a wide range of competencies. Maintainability means that the system is able to control duties to be achieved with effectiveness, efficiency, and satisfaction. In other words, usability testing is an experiment that intends to assess products for knowing usability issues, collecting eligibility information, qualitative and quantitative data on user satisfaction levels [24].

In the study [25], the authors evaluated the usability of an Amazon Kindle app. The Amazon Kindle is an electronic reader app that assists users in downloading, purchasing, getting access to online books, reading magazines, and many more. The findings have shown that the users who participated in this study already have experience with that application.

For video, a study conducted by [26] intended to address the gap in the YouTube application usability, particularly for principal areas and functions (login, upload, share, and many more) and restricting practices for teenager users. The result indicated that most participants watch YouTube for watching the video and do not consider other features in the application while doing that.

Usability is a subset of user experience telling about background information, issues, and effects encountered, helps problem identification while using the system, cooperation, replan, and restructuring results [27] [28]. However, to obtain the best findings of the usability issues, usability testing requires to be performed with five respondents [29]. Therefore, due to the pandemic, the usability testing phase was not able to be conducted. Thus, the authors focused only on the user experience test on Grab users.

\subsection{User Experience}

Mobile apps have become popular over the last two decades. A study in Brazil started with an experience when a bus could not stop at a bus stop even though passengers showed a signal to get on or off. To

Sabukunze, Arakaza (User Experience Analysis on Mobile Application Design Using User Experience

Questionnaire) 
overcome this problem, the solution is to design a mobile application that can direct passenger bus routes. Application design to improve service quality and increase user satisfaction needs to apply user experience methods [30].

User experience is not referred to internally operate as a product or service. User experience refers to working outside, connecting with the outcome [31][32]. A study conducted in Malaysia by Zahidi et al., within two cultural heritage websites showcased from cultural heritage collections, was selected to collect the results. These websites were chosen because of various character sharing; both are publicly accessible online platforms and motivate them to store cultural heritage content like user-generated content [33]. The User Experience is not only applied for mobile applications; it can also be applied for measuring the quality of web services using the user experience method[34], measuring the user experience of e-learning platforms using UEQ [35].

Usability principles are similar to the user experience questionnaire. The usability objectives are attributes of an interaction associated with users' functions to achieve their purposes. Based on the research conducted by [36], the author provided utility, ease to use, learnability, and many more. User experience objectives are the characteristics of an interaction connected to emotional learning about the general interaction with the item, such as enjoyment, innovation, and many more [37].

\subsection{User Experience Questionnaire}

This manuscript examined the interactive interface features of Grab's online transportation mobile application based on the user experience questionnaire. Much research has been carried out on the usability of online transportation, like the evaluation on Grab mobile application in Indonesia [38].

In the study conducted by Mussa, the researcher evaluated the user experience of an e-learning platform using the User experience Questionnaire. Among his participants, there were students and lecturers of the same online-learning website. The findings indicated that the platform needs some improvements in the user experience aspects [39].

Another group of researchers evaluated the user experience of the Halodoc mobile Health application using UEQ and usability testing. Based on the results, all items were good but not excellent [40]. Paramitha et al. carried out a study to evaluate a web-based academic progress information system using the User Experience Questionnaire. The findings have indicated that the study was positive because the score was more than 0.8 [41].

\section{Research Methodology}

This research was developed to investigate the analysis and interface design of Grab's online transportation mobile application. The survey was done using a questionnaire to analyze the online transportation mobile application based on the User Experience Questionnaire. In addition, a survey study has been applied in this research with UEQ (Indonesia version) to collect responses from Grab online transport users, in particular, Grab food service.

\subsection{Research instrument used}

This research adopted User Experience Questionnaire in the Indonesian language because many respondents were Indonesian citizens. This same version questionnaire was established then applied in the study carried out to calculate the UX of the education system [35]. UEQ includes a 7-point Likert scale and twenty-six elements showing the main feature. Therefore, it ensures that the questionnaire is clear and more precise.

The user experience questionnaire (UEQ) is dependent on the concept that the user experience can be computed by studying the usability and user experience objectives. This questionnaire is used to perform a user experience assessment perceived towards a product fast. There are six measurement scales in UEQ, namely [40], [42]:

Sabukunze, Arakaza (User Experience Analysis on Mobile Application Design Using User Experience Questionnaire) 
- Attractiveness: The overall impression that users feel about the product. Do our users like the product?

- Perspicuity: The ease that is felt when using the product. Is the product easy to become familiar with when used?

- Efficiency: Interaction between users and products is made quickly and efficiently.

- Dependability: The user's feelings are in control over interactions. Can system behavior be predictable by users?

- Stimulation: Pleasure and motivation obtained when using the product. Is the product is motivating and exciting when used by the user?

- Novelty: Creativity and product innovation. Does the product have a display innovative and creative so that they can interest users? The environment that real.

Based on the above explanation, the UEQ measures can be summarized as follows:

Table 1. UEQ measures and items

\begin{tabular}{lll}
\hline & Attributes & \multicolumn{1}{c}{ Items } \\
\hline 1 & Attractiveness & $\begin{array}{l}\text { annoying/enjoyable, good/bad, unlikeable/pleasing, unpleasant/pleasant, } \\
\text { attractive/unattractive, friendly/unfriendly. } \\
\text { not understandable/understandable, easy to learn/difficult to learn, } \\
\text { complicated/easy, clear/confusing. } \\
\text { fast/slow, inefficient/efficient, impractical/practical, organized/cluttered } \\
\text { unpredictable/predictable, obstructive/supportive, secure/not secure, } \\
\text { meets expectations/does not meet expectations } \\
\text { valuable/inferior, boring/exiting, not interesting/interesting, } \\
\text { motivating/demotivating } \\
\text { creative/dull, inventive/conventional, usual/leading edge, } \\
\text { conservative/innovative }\end{array}$ \\
\hline
\end{tabular}

UEQ has three principal characteristics: attractiveness, hedonic, and pragmatic quality, as displayed in Figure 1.

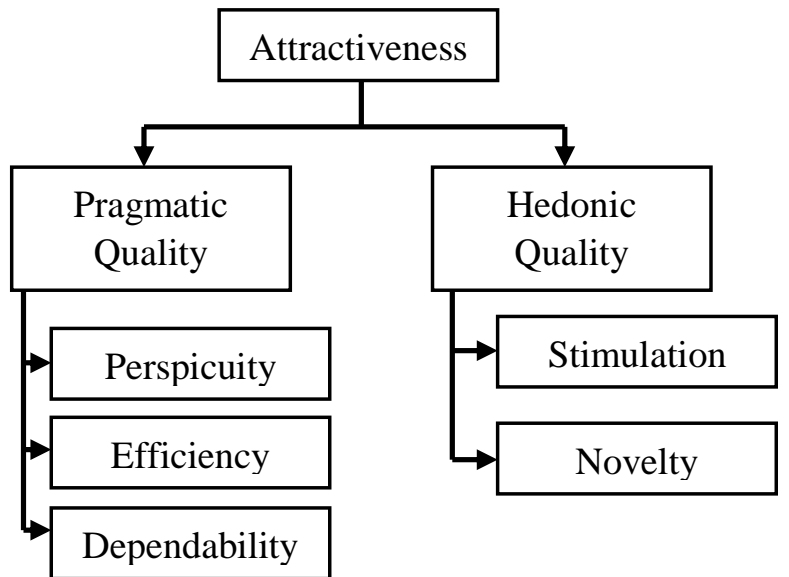

Figure 1. Design of the UEQ [42]. 


\subsection{Questionnaire survey}

The instrument was prepared and converted to Google Forms then distributed via WhatsApp. In other words, Google Forms was distributed to numerous Grab online transportation users that have already used Grab food service.

The participants were given a questionnaire involving items from the items described in the research design used section. This stage examines the level of satisfaction and agreement with the user experience for Grab mobile application based on the 7-point Likert scale as in Figure 2.

\subsection{Participants}

The respondents of the questionnaire are those with the following characteristics: a) participants that had already used Grab online transportation mobile application especially Grab food service, b) located in Yogyakarta city in Indonesia, c) willingly to participate in this study.

This research attracted 90 (100\%) participants freely and helped authors to assess the usability of the Grab mobile application. Among the 90 participants, 45 were females (50\%), and $45(50 \%)$ were males. Furthermore, all the 90 participants between the ages of 18 to 25 were 63, and those above 25 were 27 participants. Moreover, 62 were students, two (2) lecturers, and the rest worked in different sectors, and all were located in Yogyakarta.

Before analyzing data, the authors started by doing pre-treatment data because we realized that some participants responded without seriousness. The detected suspicious data were for 6 participants, which means we remain with 84 participants.

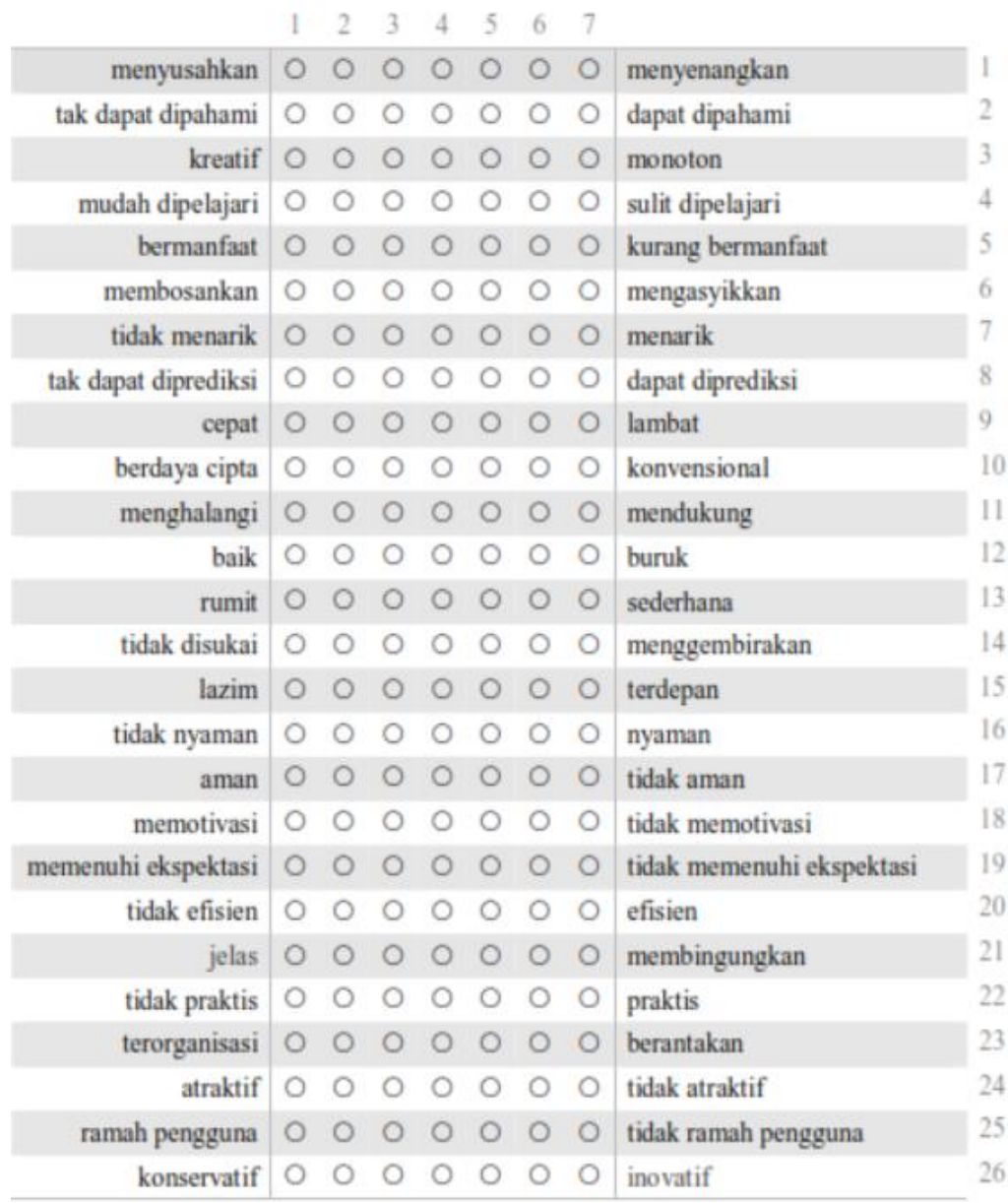

Figure 2. UEQ (Indonesian Version) 


\section{Result and discussion}

\subsection{The Cronbach's Alpha}

The findings of Alpha coefficient values of the scales of this study is presented in Table 2. The calculated Cronbach's Alpha of all UEQ scales usually indicated satisfaction of the values, which means that Alpha's value is more than 0.7. A combination of new values has a value lower than 0.7 , except the Novelty scale, which is lower than 0.7 .

Table 2. Cronbach's Alpha coefficient

\begin{tabular}{lc}
\hline \multicolumn{1}{c}{ UEQ Scale } & Cronbach's Alpha Coefficient \\
\hline Attractiveness & 0.89 \\
Perspicuity & 0.86 \\
Efficiency & 0.76 \\
Dependability & 0.80 \\
Stimulation & 0.75 \\
Novelty & 0.68 \\
\hline
\end{tabular}

The Alpha coefficient of the novelty scale is smaller than 0.7 , which might be obtained because the Grab food service does not make a great essential for Grab mobile application users. For that reason, it means that the reliability of the UEQ scales is high based on the statement of study [35].

\subsection{Interpretation of the findings}

This section analyzed the value of the UEQ measures' findings, and the sample given in the Excel tool used to analyze data. This juxtaposition is essential and the first sign of knowing whether the software or website assessed has a good UX to be called effective and fruitful. Hence, it is necessary to compare and relate to the benchmark value to identify the frailties and strengths of the assessed system. Table 3 represents the mean coefficients of UEQ measures of the benchmark data compared with any examined system's values.

Table 3. Benchmark gaps for the UEQ scales[43].

\begin{tabular}{lllllll}
\hline & Attr. & Effect. & Perpec. & Depend. & Stimul. & Novel. \\
\hline Excellent & $\geq 1.75$ & $\geq 1.78$ & $\geq 1.9$ & $\geq 1.65$ & $\geq 1.55$ & $\geq 1.4$ \\
Good & $\geq 1.52$ & $\geq 1.47$ & $\geq 1.56$ & $\geq 1.48$ & $\geq 1.31$ & $\geq 1.05$ \\
& $<1.75$ & $<1.78$ & $<1.9$ & $<1.65$ & $<1.55$ & $<1.4$ \\
Above average & $\geq 1.17$ & $\geq 0.98$ & $\geq 1.08$ & $\geq 1.14$ & $\geq 0.99$ & $\geq 0.71$ \\
& $<1.52$ & $<1.47$ & $<1.56$ & $<1.48$ & $<1.31$ & $<1.05$ \\
Below average & $\geq 0.7$ & $\geq 0.54$ & $\geq 0.64$ & $\geq 0.78$ & $\geq 0.5$ & $\geq 0.3$ \\
Bad & $<1.17$ & $<0.98$ & $<1.08$ & $<1.14$ & $<0.99$ & $<0.71$ \\
& $<0.7$ & $<0.54$ & $<0.64$ & $<0.78$ & $<0.5$ & $<0.3$ \\
\hline
\end{tabular}

Meanwhile, Table 4 below shows the measure of scales in the overall responses of our respondents.

Table 4. The UEQ Scale Means

\begin{tabular}{lc}
\hline \multicolumn{1}{c}{ Scale } & Mean \\
\hline Attractiveness & 1.64 \\
Perspicuity & 1.69
\end{tabular}




\begin{tabular}{lc}
\hline \multicolumn{1}{c}{ Scale } & Mean \\
\hline Efficiency & 1.6 \\
Dependability & 1.29 \\
Stimulation & 1.57 \\
Novelty & 1.21 \\
\hline
\end{tabular}

Table 4 indicates the outcome of means calculations for every scale by revealing either the findings are positive, negative, or average. Based on the literature [44], if the excel data analysis tool has upward arrows, it signifies that the findings are positive. The overall findings of the Grab mobile application are illustrated in Figures 3 and 4. The value of each UEQ item is displayed in Figure 3.

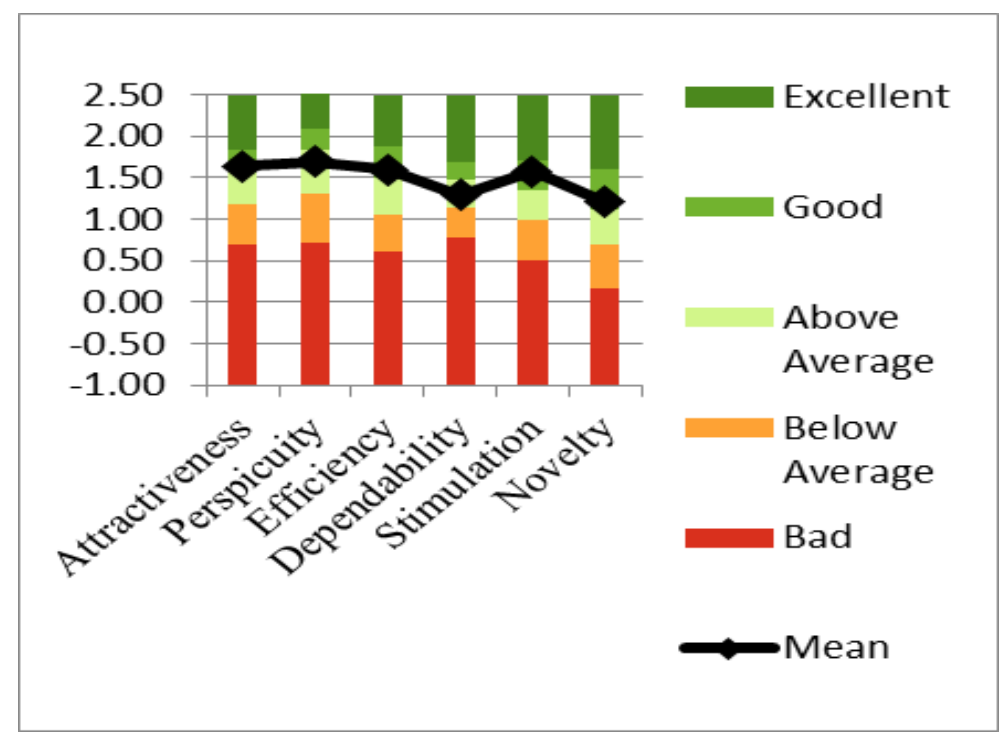

Figure 3. Average UEQ scale values of the Grab application design

The findings acquired by filling out the questionnaires are to give weight to each scale by rating from -3 (very bad) to +3 (excellent), as stated in the study [44].

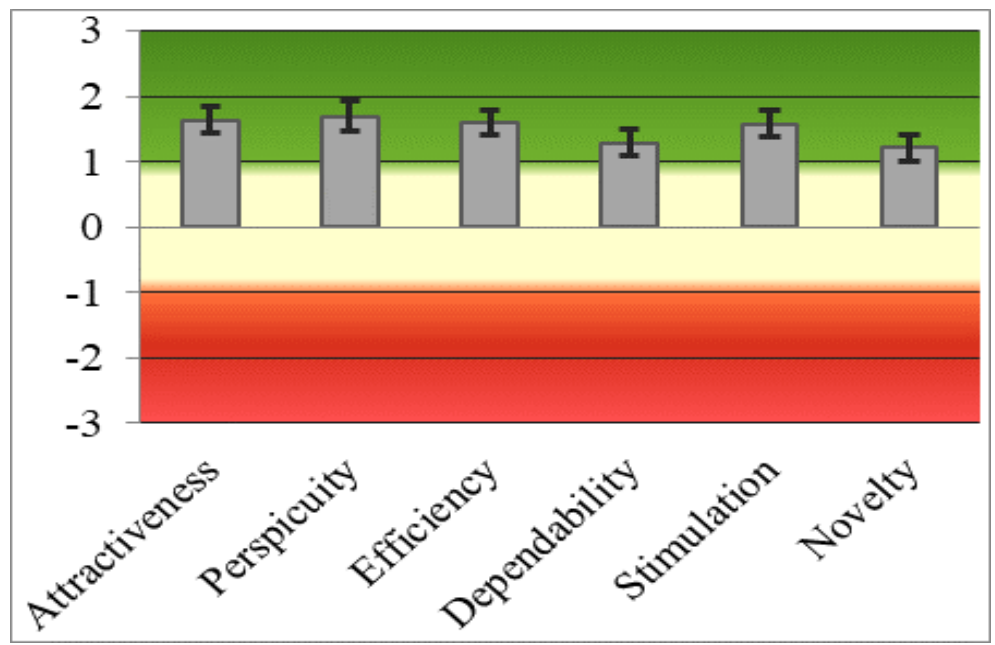

Figure 4. UEQ benchmark diagram on the Grab application. 
The overall outcome of the Grab mobile application is illustrated in Table 5, Figure 2 and 3. The value of each scale can be seen, where the Attractiveness scale is 1.64, Efficiency 1.60, Perspicuity 1.69, Stimulation 1.57, Dependability 1.29, and Novelty 1.21 . Referring to the benchmark of the UEQ in the reference [43], the findings of the UEQ are in the relative normal range. Generally, the hedonic quality values (1.39) are lower than the pragmatic quality (1.53).

The findings from respondents designated that all UEQ measures are coherent like Alpha values were more significant than 0.7. Consequently, from the conclusions given in Table 3, the outcomes from participants reveal items except the Novelty are in a good category, with Cronbach's Alpha which is equal to or greater than 0.7 as stated in the study [33].

Table 5 and Figure 2 show that the dependability scale has only shown a mean value above average. The other scale is in a good category based on the UEQ benchmark, as shown in Table 4. Furthermore, Table 3 indicated that Novelty's alpha value is less than 0.7 , which might be obtained because the Grab food service does not make a great essential for Grab mobile software users.

\section{Conclusion}

This study intended to analyze the user experience of the online transportation mobile application called Grab 5.158.0, especially for Grab food services considering the complaints in the Play Store. The survey of online transportation applications was conducted using a user experience questionnaire (UEQ) method, with users from Yogyakarta as the respondents. Based on the results displayed above, it can be summarized that the scale means of the Grab online transportation for Grab foodservice users is reasonable because several of them are in a good category compared to the values in the UEQ benchmark. The findings have shown a good indication of users' experience of the Grab mobile application because all values are above 0.8. Distinctly, there is a degree of difference between pragmatic quality scales (perspicuity, Efficiency, and dependability) and the other Hedonic Quality (Stimulation and Novelty). The recommendation regarding the result is improvement on the dependability variable.

Future studies hope to find more participants for data collection and use other usability testing methods and interviews.

\section{Limitations}

This research depends on the survey and has limitations. Due to the pandemic, the researchers only conducted the survey on the user experience but not on the usability testing methods.

\section{Acknowledgement}

The authors' gratitude goes to the University Atma Jaya Yogyakarta especially to the Department of Informatics Engineering and the International Office. The authors would also express gratitude to Alexis Arakaza in Burundi, a lecturer to ISGE for the assistance.

\section{References}

[1] F. Hujainah, H. Dahlan, and B. Al-haimi, "Usability Guidelines of Mobile Learning Application," J. Inf. Syst. Res. Innov., vol. 5, no. 2, pp. 70-77, 2013.

[2] Z. Huang and Z. Tian, Analysis and Design for Mobile Applications: A User Experience Approach, vol. 10918. Springer International Publishing, 2018.

[3] J. M. C. Bastien, "Usability testing: a review of some methodological and technical aspects of the method," Int. J. Med. Inform., vol. 79, no. 4, 2010, doi: 10.1016/j.ijmedinf.2008.12.004.

[4] D. Benyon, Designing Interactive Systems and interaction design. 2005.

[5] O. Álvarez-Xochihua, P. J. Muñoz-Merino, M. Muñoz-Organero, C. D. Kloos, and J. A. González- 
Fraga, "Comparing usability, user experience and learning motivation characteristics of two educational computer games," ICEIS 2017 - Proc. 19th Int. Conf. Enterp. Inf. Syst., vol. 3, no. Iceis, pp. 143-150, 2017, doi: 10.5220/0006338901430150.

[6] A. H. Katy, "Measuring Usability for Application Software Using the," no. March, p. 42, 2016.

[7] C. Baird, "Useful, Usable, Desirable: Applying User Experience Design to Your Library," $J$. Electron. Resour. Librariansh., vol. 27, no. 2, pp. 142-143, 2015, doi: 10.1080/1941126x.2015.1029781.

[8] R. Roth, "User Interface and User Experience (UI/UX) Design," Geogr. Inf. Sci. Technol. Body Knowl., vol. 2017, no. Q2, 2017, doi: 10.22224/gistbok/2017.2.5.

[9] M. Orlova, "Mariia Orlova USER EXPERIENCE DESIGN (UX DESIGN) IN A WEBSITE DEVELOPMENT Website redesign Mariia Orlova," no. December, 2016, [Online]. Available: http://www.theseus.fi/handle/10024/120948.

[10] A. Hinderks, M. Schrepp, F. J. Domínguez Mayo, M. J. Escalona, and J. Thomaschewski, "Developing a UX KPI based on the user experience questionnaire," Comput. Stand. Interfaces, vol. 65, no. January, pp. 38-44, 2019, doi: 10.1016/j.csi.2019.01.007.

[11] R. A. C. Reis, L. L. A. Gomes, A. C. Dias-Neto, and A. de L. Fontão, "Usability Evaluation Approaches for (Ubiquitous) Mobile Applications: A Systematic Mapping Study," UBICOMM 2015 Ninth Int. Conf. Mob. Ubiquitous Comput. Syst. Serv. Technol. Usability, pp. 11-17, 2015.

[12] A. Ali, M. Alrasheedi, and A. O. and L. F. Capretz, "A Study of the interface usability issues of mobile learning applications for smartphones from the user's perpective," Litejnoe Proizv., vol. 3, no. 3, pp. 11-15, 2014.

[13] D. L. Tungkup, "The Importance of Online Transportation Effectiveness for Business Resistance Strategies During the Covid-19 Pandemic," KnE Soc. Sci., vol. 2020, no. Iwpospa, pp. 396-414, 2021, doi: 10.18502/kss.v5i1.8302.

[14] M. Y. Alfiqie, "Evaluasi Usability Pada Aplikasi UBER Menggunakan Pengujian Usability," $J$. Pengemb. Teknol. Inf. dan Ilmu Komput., vol. 2, no. 9, pp. 2599-2606, 2018, [Online]. Available: http://j-ptiik.ub.ac.id/index.php/j-ptiik/article/view/2367.

[15] A. Hussain, E. O. C. Mkpojiogu, A. Jama Isse, and R. A. Mohammed, "Grab mobile application: A usability evaluation," AIP Conf. Proc., vol. 2016, no. September, 2018, doi: 10.1063/1.5055456.

[16] T. Pancar, M. Holthaus, and P. B. Bergamin, "Enhanced System Usability Scale for Adaptive Courses.," Twelfth Int. Conf. Adv. Human-oriented Pers. Mech. Technol. Serv. CENTRIC 2019, no. March 2020, 2019.

[17] J. R. Lewis, "Measuring Perceived Usability: The CSUQ, SUS, and UMUX," Int. J. Hum. Comput. Interact., vol. 34, no. 12, pp. 1148-1156, 2018, doi: 10.1080/10447318.2017.1418805.

[18] P. Weichbroth, "Usability of mobile applications: A systematic literature study," IEEE Access, vol. 8, no. March, pp. 55563-55577, 2020, doi: 10.1109/ACCESS.2020.2981892.

[19] K. Majrashi, M. Hamilton, A. L. Uitdenbogerd, and S. Al-Megren, "Cross-platform usability model evaluation," Multimodal Technol. Interact., vol. 4, no. 4, pp. 1-23, 2020, doi: 10.3390/mti4040080.

[20] J. C. Pitt and A. Shew, Spaces for the future: A companion to philosophy of technology. 2017.

[21] T. Tullis and B. Albert, Measuring the User Experience: Collecting, Analyzing, and Presenting Usability Metrics: Second Edition. 2013.

[22] I. O. for S. (ISO), "Ergonomics of human-system interaction - Part 11: Usability: Definitions and Concepts," Iso 9241-112018(E), no. November, p. 2, 2018, [Online]. Available: https://infostore.saiglobal.com/preview/is/en/2018/i.s.eniso9241-112018.pdf?sku=1980667\%0Ahttps://www.sis.se/api/document/preview/80003410/.

[23] N. Bevan, J. Carter, J. Earthy, T. Geis, and S. Harker, "New ISO standards for usability, usability reports and usability measures," Lect. Notes Comput. Sci. (including Subser. Lect. Notes Artif. Intell. Lect. Notes Bioinformatics), vol. 9731, no. July 2018, pp. 268-278, 2016, doi: 10.1007/978- 
3-319-39510-4_25.

[24] R. Yuwono, A. Wibowo, S. H. Wijoyo, and R. I. Rokhmawati, “Analisis Pengalaman Pengguna Pada Aplikasi Mobile Banking di Indonesia Dengan Menggunakan Usability Testing dan User Experience Questionnaire (UEQ) (Studi pada JakOne Mobile dan BCA Mobile)," J. Pengemb. Teknol. Inf. dan Ilmu Komput., vol. 3, no. 6, pp. 5666-5673, 2019.

[25] A. Hussain, E. O. C. Mkpojiogu, J. Musa, and S. Mortada, "A user experience evaluation of Amazon Kindle mobile application," AIP Conf. Proc., vol. 1891, no. October, 2017, doi: 10.1063/1.5005393.

[26] A. Hussain, M. N. F. A. Razak, E. O. C. Mkpojiogu, and M. M. F. Hamdi, "UX evaluation of video streaming application with teenage users," J. Telecommun. Electron. Comput. Eng., vol. 9, no. 211, pp. 129-131, 2017.

[27] A. Følstad, E. L. C. Law, and K. Hornbæk, "Analysis in practical usability evaluation: A survey study," Conf. Hum. Factors Comput. Syst. - Proc., pp. 2127-2136, 2012, doi: 10.1145/2207676.2208365.

[28] M. Nieminen, "Usability, User Experience, and Emotions," [Online]. Available: https://indico.cern.ch/event/473279/attachments/1224300/1791455/CERN-IdeaSqr-UX-2016-0113_.pdf.

[29] K. Moran, "Usability Testing 101," 2019. https://www.nngroup.com/articles/usability-testing-101/ (accessed Jun. 13, 2021).

[30] S. Sajjad, D. M. Khan, N. Saher, and F. Shahzad, "The usability analysis of mobile interfaces," Sci.Int.(Lahore), vol. 28, no. 2, pp. 1097-1103, 2016.

[31] M. Deaton, The elements of user experience: user-centered design for the Web, vol. 10, no. 5. 2003.

[32] Díaz-Oreiro, López, Quesada, and Guerrero, "Standardized Questionnaires for User Experience Evaluation: A Systematic Literature Review," Proceedings, vol. 31, no. 1, p. 14, 2019, doi: 10.3390/proceedings2019031014.

[33] Z. Zahidi, Y. P. Lim, and P. C. Woods, "Understanding the user experience (UX) factors that influence user satisfaction in digital culture heritage online collections for non-expert users," Proc. 2014 Sci. Inf. Conf. SAI 2014, pp. 57-63, 2014, doi: 10.1109/SAI.2014.6918172.

[34] R. K. Paredes and A. A. Hernandez, "Measuring the quality of user experience on web services: A case of university in the Philippines," HNICEM 2017 - 9th Int. Conf. Humanoid, Nanotechnology, Inf. Technol. Commun. Control. Environ. Manag., vol. 2018-Janua, pp. 1-6, 2017, doi: 10.1109/HNICEM.2017.8269446.

[35] H. B. Santoso, M. Schrepp, R. Yugo Kartono Isal, A. Y. Utomo, and B. Priyogi, "Measuring user experience of the student-centered E-learning environment," J. Educ. Online, vol. 13, no. 1, pp. 179, 2016.

[36] I. Begum, "Hci and Its Effective Use in Design and Development of Good User Interface," Int. J. Res. Eng. Technol., vol. 03, no. 15, pp. 176-180, 2014, doi: 10.15623/ijret.2014.0315033.

[37] H. Sharp, Y. Rogers, and J. Preece, Interaction design:Beyond human_computer Interaction 5th $E d$, 5th ed. John Wiley \& Sons, Inc. 10475 Crosspoint Boulevard Indianapolis, IN 46256 www.wiley.com Copyright, 2019.

[38] A. Hussain, E. O. C. Mkpojiogu, A. Jama Isse, and R. A. Mohammed, "Grab mobile application: A usability evaluation," AIP Conf. Proc., vol. 2016, no. October, pp. 1-6, 2018, doi: 10.1063/1.5055456.

[39] M. S. Abubakari, Nurkhamid, and G. Hungilo, "Evaluating an e-Learning Platform at Graduate School Based on User Experience Evaluation Technique," J. Phys. Conf. Ser., vol. 1737, no. 1, 2021, doi: 10.1088/1742-6596/1737/1/012019.

[40] Mochammad Aldi Kushendriawan, Harry Budi Santoso, Panca O. Hadi Putra, and Martin Schrepp,

Sabukunze, Arakaza (User Experience Analysis on Mobile Application Design Using User Experience Questionnaire) 
"Evaluating User Experience of a Mobile Health Application' Halodoc' using User Experience Questionnaire and Usability Testing," J. Sist. Inf., vol. 17, no. 1, pp. 58-71, 2021, doi: 10.21609/jsi.v17i1.1063.

[41] A. A. I. I. Paramitha, G. R. Dantes, and G. Indrawan, "The evaluation of web based academic progress information system using heuristic evaluation and user experience questionnaire (UEQ)," Proc. 3rd Int. Conf. Informatics Comput. ICIC 2018, pp. 1-6, 2018, doi: 10.1109/IAC.2018.8780430.

[42] M. Schrepp, "User Experience Questionnaire Handbook Version 8," URL https//www. Res. net/publication/303880829_User_Experience_Questionnaire_Handbook_Version_2.(Accessed 02.02. 2017), no. September 2015, pp. 1-15, 2019, [Online]. Available: www.ueq-online.org.

[43] M. Schrepp, A. Hinderks, and J. Thomaschewski, "Construction of a Benchmark for the User Experience Questionnaire (UEQ)," Int. J. Interact. Multimed. Artif. Intell., vol. 4, no. 4, p. 40, 2017, doi: 10.9781/ijimai.2017.445.

[44] K. T. MARTONO, "Analysis on User Experience Using UEQ Method in the Information System of Web-Based Child Development Monitoring," SSRN Electron. J., vol. 2016, 2021, doi: $10.2139 /$ ssrn.3794981. 